\begin{abstract}
Iranica
Abstracta Iranica Revue bibliographique pour le domaine irano-aryen

Volume 32-33 | 2013

Comptes rendus des publications de 2009-2010
\end{abstract}

\title{
Graham Williamson. The Turko-Persian War 1821-1823
}

Jean Calmard

\section{(2) OpenEdition}

\section{Journals}

Electronic version

URL: http://journals.openedition.org/abstractairanica/40694

DOI: 10.4000/abstractairanica.40694

ISSN: 1961-960X

\section{Publisher:}

CNRS (UMR 7528 Mondes iraniens et indiens), Éditions de l'IFRI

\section{Printed version}

Date of publication: 1 December 2013

ISSN: 0240-8910

\section{Electronic reference}

Jean Calmard, «Graham Williamson. The Turko-Persian War 1827-1823 », Abstracta Iranica [Online], Volume 32-33 | 2013, document 263, Online since 01 July 2016, connection on 26 September 2020. URL : http://journals.openedition.org/abstractairanica/40694; DOI : https://doi.org/10.4000/ abstractairanica.40694

This text was automatically generated on 26 September 2020.

Tous droits réservés 


\title{
Graham Williamson. The Turko- Persian War 1821-1823
}

\author{
Jean Calmard
}

\section{REFERENCES}

Graham Williamson. "The Turko-Persian War 1821-1823 », in : Roxane

Farmanfarmaian, ed., War and Peace in Qajar Persia. Implications Past and Present. London \& New York, Routledge, p. 88-109. (History and Society in the Islamic World)

Besides referring to the critical remarks formulated in my review of this book in St. Ir. 39/2, p. 295-299), I would like to insist on a few points. The article is drawn from British archives and published travel accounts (for instance, the Travels of Sir Robert Ker Porter who is cited as "Ker Porter"). Articles from Encyclopcedia Iranica are cited without the author's name. The text abounds in spelling and historical errors. Place names for decisive battles are misspelled or not given: Toprah Kaleh for Toprak Qal'e on the northern front, nothing for the southern front (See my forthcoming study on the battle of Shahrezur). The name of the governor of Soleymāniye, Mahmūd Pāšā Bābān, has become "Mahommad Pasha" (p. 93); his replacement was the main pretext for the war against Ottoman Iraq. The "feudal army of Mohammad Ali Mirza" (p. 94), having been equipped and drilled by European officers, severely defeated the Ottomans. To its merit, this article has drawn information from British testimonies; but these are uncritically presented, and Persian as well as and French sources having been neglected. 


\section{AUTHORS}

JEAN CALMARD

CNRS - EPHE, Paris 